\title{
Reservoir Device
}

National Cancer Institute

\section{Source}

National Cancer Institute. Reservoir Device. NCI Thesaurus. Code C50140.

A vessel designed to store a fluid. 